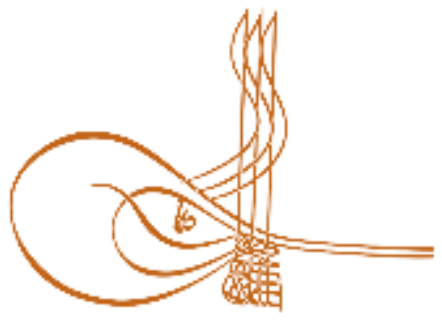

www.turkishstudies.net/social
Turkish Studies - Social Sciences

eISSN: $2667-5617$

Research Article / Araşttrma Makalesi

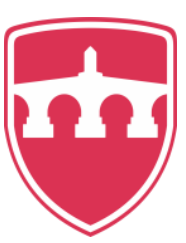

INTERNATIONAL

BALKAN

UNIVERSITY

Sponsored by IBU

\title{
Teknoloji Kullanmanın Dindar Kadınların Hayat Tarzına Etkisi"
}

The Impact of Technological Developments upon the Lifestyles of the Religius Women

\author{
Funda Eldemir $^{* *}$
}

\begin{abstract}
There has always been a close relationship between technology and lifestyles. Although it is known that there is a dialectical relationship between technological development, human mentality, life practices and society, according to many thinkers, this relationship is more effective on culture, human and society. So much so that the technique that human beings produce as a remedy against nature has become one of the factors that put distances between it and nature. However, it is difficult to say that the instruments used to solve certain and urgent problems of life, with exceptions, completely destroy the reputation of the culture in which they are made available. Technique, which is the ability of man to produce, has a feature that distinguishes him from all other living beings. The validity of these comments is a matter of debate. Because every phenomenon should be evaluated within its own social, political, religious and cultural conditions. The aim of this study is to understand how using technology affects the lifestyle of religious women. For this purpose, firstly, a literature survey was conducted on the subject, and then in-depth interviews were made with eighteen religious women who are educated, middle-high income, married, and their parents religious. The effects of technology usage were analyzed by considering the statements of the participants. The effects of using technology include that convenience at learning, teaching and experiencing religious knowledge, change religious life traditions.
\end{abstract}

Structured Abstract: It is known that there is a dialectical relationship between technological development, human mentality, life practices and society. According to many thinkers, in this relationship, the culture produced by technology is more effective on people and society. So much so that the technique produced by mankind against nature has become one of the factors that put distance between it and nature.

What is the connection between technology and society? Is technology focused on a new social environment? How are women who are religious, referring to life (in the world) and referring to "religion olarak as their lifestyle affected by the environment created by technology? How did the practices of religious life change in the plan that internalized the beliefs, principles, practices and symbols of the religion of which it belongs and displayed them in their attitudes and behaviors?

\footnotetext{
* Bu çalışma yazarın aynı adlı tezinden hazırlanmıştır.

*** Elektrik Elektronik Mühendisi, Doktora Öğrencisi, Ankara Üniversitesi Felsefe ve Din Bilimleri Anabilim Dalı Din Psikolojisi Bilim Dalı

Electrical Electronics Engineer, Phd Student, Ankara University, Faculty of Theology, Department of Philosophy and Religious Sciences, Department of Psychology of Religion

ORCID 0000-0001-9579-2036

funzeh@hotmail.com
}

Cite as/ Atıf: Eldemir, F. (2020). Teknoloji kullanmanın dindar kadınların hayat tarzına etkisi, Turkish Studies - Social, 15(3), 1127-1147. https://dx.doi.org/10.29228/TurkishStudies.39390

Received/Geliş: 20 October/Ekim 2019

Accepted/Kabul: 25 April/Nisan 2020

Checked by plagiarism software

Copyright $(C)$ INTAC LTD, Turkey 
This study aims to analyze the concrete results of this interaction with in-depth interview technique on religious women. In this context, if the religious woman's relationship with technology, especially in the way of religious life "Has there been a change?". How has this change occurred? answers to these questions will be sought in the light of the contributions of the participants. it is true that there are enough studies on the effects of technological developments. There are also studies on the lifestyle of religious women. However, there is a lack of research specifically addressing the impact of technological advances on the lifestyle of religious women, particularly on religious sensitivities. this makes the research meaningful and original.

\section{Research Workıng Group}

Research universe itself religious in Turkey, have higher education, are 18 women living in Bursa using technology. The whole study group consists of middle and high income, headscarf, religious families, religious education, occupations, born between 1969-1990, especially married and children.

\section{Qualifications Of The Sample}

Participants were educated social and married women who stated that they had religious sensitivity in their private life. Because of the high potential of using sample technology, educated individuals with middlemiddle upper layer income were selected. In order to allow comparison with the previous generation, care was taken to ensure that their families were conservative. In this way, it was paid attention that the participants had religious equipment and education. Religious sensitivities of those who live in religious life wearing headscarves in Turkey research results (Religious Life Survey, Turkey, 2014: 106) were considered and the sample is selected considering all veiled.

The sample of this study was determined as women with headscarves and those born between 1969 and $1990.5 \%$ (1) of the participants were between 25-30 years old, 40\% (7) were between 30-35 years old, $10 \%$ (2) were between 35-40 years old, $40 \%$ (7) were between 40-45 years old, 5\% (1) person is over 45 years of age. acceleration of economic-technological development that occurred after the 1970s in Turkey, so this age group were selected. Since this age group can observe the previous period, they can put forward the social change in life style better. (Okutan, 2013: 15)

\section{Method}

The study was conducted with in-depth interview technique, also called structured interview or ethnographic interview. Participants were reached by using snowball sampling selection technique, also called chain sampling selection technique. Semi-structured interview was conducted. In order to conduct the interviews, a series of questions were prepared to be used in all interviews. The questions were reorganized with limited flexibility. In addition to the face of the in-depth interview, which tells the individual the world of emotion and thought, and offers the opportunity to share her ideas and experiences, the lifestyle visualizes from the gestures and mimics of the subject to the clothing style and the goods she uses, and in a way the background of the sentences reflects the mind world. (Okutan, 2013: 18)

As for limited sampling, we chose a small sample group in a time-consuming research technique such as in-depth interviewing. Data analysis was performed at the same time. The same answers began to be received from the participants. The theoretical saturation point was reached and interviews with 18 people were accepted as satisfactory.

Face-to-face interviews were usually conducted at the participants' homes and impressions of lifestyle were noted. The principle that the interviews made with voice recording will be confidential has enabled the participants to answer all kinds of questions easily.

\section{Findings}

\section{EASY OF RELIGIOUS LEARNING, TEACHING AND LIVING}

The development of technology has brought about a change in the traditional way of learning, teaching and religious life of religion.

\section{RELIGIOUS TEACHING, LEARNING}

Quran teacher (participant 12) sees Quran programs and projection as a great helper. 
Participant9 interprets the teaching sets of the Qur'an and the items that read the Qur'an as the liberation of the children from the authoritarian teachers.

Participant2 said that the husband of her performed the Quran memorization over the internet.

Participant11 says that getting religious information from different hodja on TV has changed a strict religious understanding.

\section{EASE OF WORSHIP} Quran.

Participant16 says that her father did not have to carry the Quran thanks to the pen used to read the

Participant9 stated the ease of chanting with 'zikirmatik' and the possibility of listening to the Quran during Ramadan.

\section{CHANGING THE RELIGIOUS LIFE TRADITION}

Religious women's intense engagement with technology has created new religious life sensitivities.

\section{CHANGE OF PERCEPTION OF SIN}

Participation3 and participant11 define social media as a particularly gossip and a means of provocation. She says that all kinds of lies are considered very fast as a result of the fact that the information here is not questioned.

Participant5 tells that the virtual is not accepted as a sin and that Muslims who do not do it in normal life gamble on the internet and watch porn.

\section{CHANGE OF VALUES}

\section{Donate} new things

Giving the participants was to give the things they love in the past, now they give it to make room for

\section{Patience}

The Islamic religion recommends patience, but the sense of speed that new technologies bring abolishes patience.

\section{Satisfactory}

Participant17 says that their needs are increasing and they are not easily satisfied.

\section{Contemplation}

The participant8 states that the environment of contemplation that created contact with nature has ceased because of technology.

\section{DECREASE IN TIME AWARENESS.}

Participant 10 and participant9 agree that the time spent with technology prevents worship.

\section{CELEBRATION TRADITION} commodity.

Participant15 said that religious holidays and religious days have become a virtual celebration

\section{Results And Suggestion}

Is there a change in lifestyle when religious women connect with technology? If so, what kind of change is this and what is its nature? On what concrete examples has this change become visible? In the study conducted around the above questions, the following conclusions were reached. The thesis that each new technology brings with it a new religious lifestyle remains largely valid.

In the dimension of religious life, the ease of learning religion brought about by technology is perceived very positively by the participants. It emphasizes the ease of using technological tools in Quran 
reading, memorization and listening. Participants agree that ease of access to religious knowledge and pluralism soften the strict traditional religious understanding of their parents and make religion more livable. This situation changes the frightening understanding of religion.

All these situations require updating religious information and fatwas. While Mushaf was not kept without ablution, what would be the situation while opening or touching the items that read the Quran or Ipad, Quran, which was transferred to the screen, or laptop or smart phones? Also, is it the same to listen to the Quran in the virtual environment and in the real environment? Consequently, the following determination is important; Religious rituals are experienced without much need for institutional (mosque, teacher, community, Mushaf) religious tools, which are indispensable for living religion. Religion moves to a more subjective area. According to its function, technology is accepted either as a means of religious life or as a means of entering into sin. Religious protection rituals (Euzubesmele) are also needed when using technology.

Giving was to give the things they love in the past, now they give it to make room for new things. The Islamic religion recommends patience, but the sense of speed that new technologies bring abolishes patience. the environment of contemplation that been created contact with nature been ceased because of technology. Participants have agreed that the time spent with technology prevents worship.

In addition, due to the dependence developed by the technology, it is observed that the awareness of worship decreases, the traditional forms of celebration of religion (virtual messages instead of visits) change and virtual superstitions increase

A result it was concluded that the use of technology changed the lifestyle. The target group of this study is limited to educated and middle-income women who define themselves as religious. Conducting similar studies on other segments of society may give a more holistic result.

In addition, it provides a limited perspective as it is conducted with fewer participants in the in-depth interview method.

A survey with a larger sample size may provide a wider perspective. With such studies, awareness can be raised that technology is not innocent and can have negative effects on people's lifestyle. The efforts to minimize or eliminate these effects may be the subject of another study.

Keywords: Technology, religious women, lifestyles

Öz: Teknoloji ile hayat tarzı arasında her zaman yakın bir ilişki tarih boyu hep var olagelmiştir. Teknolojik gelişme ile insan zihniyeti, yaşam pratikleri ve toplum arasında diyalektik bir ilişki olduğu bilinmekte ise de pek çok düşünüre göre, bu ilişkide teknolojinin ürettiği kültür, insan ve toplum üzerinde daha etkindir. Öyle ki, insanoğlunun, doğayla baş etmek için ürettiği çare olarak görülen teknik, bir süre sonra insanı ve toplumu kuşatarak, onunla doğa arasına mesafeler koyan etmenlerden biri haline gelmiştir. Bununla birlikte, Hayatın belirli ve acil problemlerine çözüm için kullanılan aletlerin, istisnaları olmakla birlikte, kullanıma sunuldukları kültürün itibarı bütününe tümüyle yok ettiğini söylemek zordur. İnsanın üretme becerisi olan teknik, bu yönüyle onu diğer tüm canlılardan ayıran bir özelliğe sahiptir. Bu yorumların ne denli geçerli olduğu tartışmaya açık bir konudur. Zira her olgu kendi sosyal, siyasal, din ve kültürel şartları içinde değerlendirilmesi gerekir. $\mathrm{Bu}$ çalışmanın amacı da teknoloji kullanmanın dindar kadınların hayat tarzının nasıl etkilediğini anlamaktır. $\mathrm{Bu}$ amaçla önce konu ile ilgili literatür araştırması yapılmış sonrasında da eğitimli ve orta üst gelir düzeyine sahip, evli, anne babası dindar olan on sekiz dindar kadınla derinlemesine mülakat yapılmıştır. Katılımcıların ifadeleri dikkate alınarak teknoloji kullanımının etkileri analiz edilmiştir. Teknoloji kullanmanın etkileri arasında dini bilgiyi öğrenme, öğretme, yaşama dini yaşam geleneğini değiştirmesi sayılabilir.

Anahtar Kelimeler: Teknoloji, dindar kadın, yaşam tarzı

\section{Giriş}

Teknolojik gelişme, insan zihniyeti, yaşam pratikleri ve toplum arasında diyalektik bir ilişki olduğu bilinmekte ise de pek çok düşünüre göre, bu ilişkide teknolojinin ürettiği kültür, insan ve toplum üzerinde daha etkindir. Öyle ki, insanoğlunun, doğaya karşı ürettiği çare olarak görülen 
teknik, bir süre sonra insanı kuşatarak, onunla doğa arasına mesafeler koyan etmenlerden biri haline gelmiştir. Bununla birlikte, Postman'a göre," Hayatın belirli ve acil problemlerine çözüm için kullanılan aletlerin, istisnaları olmakla birlikte, kullanıma sunuldukları kültürün itibarı bütününe tümüyle tecavüz ettiğini söylemek zordur (Postman,2009:25). İnsanın üretme becerisi olan teknik, bu yönüyle onu diğer tüm canlılardan ayıran bir özelliğe sahiptir. Bu yorumların ne denli doğru olduğu, her olgu kendi sosyal, siyasal, din ve kültürel şartları içinde değerlendirilerek tartışılmalıdır.

Toplum, Sanayi devrimi sonrası makinelerin hakimiyeti ile birlikte, esirlerin ve işçilerin alın terine değil de makinelerin gücüne dayanan bir topluma dönüşmüştür. İnsanın üretme edimi bir müddet sonra kontrol edilemez hale gelmiş, Marks'nn (Slattery,2008:123) ifadesiyle, kontrol edilemeyen üretme tutkusu, insanı kendine ve ürettiğine yabancılaştırmıştır. İnsanın işlevsel bir dünya kurma çabası olan teknik, başlangıçta insan ve doğa ile barışçıl bir ilişki içindeyken, zamanla toplumsal, siyasal ve ekonomik bir nitelik kazanarak boyut değiştirmiştir.

Teknoloji ile toplum arasında nasıl bir ilişki vardır? Teknoloji yeni bir toplumsal ortam oluşturmakta mıdır? Dindar, hayata bakışı (dünya görüşü) ve yaşam tarzı olarak dini referans alan kadınlar teknolojinin oluşturduğu ortamdan etkilenmiş midir? Mensubu olduğu dinin inanç, ilke, pratik ve sembollerini içselleştirip bunları tutum ve davranışlarında sergileyen kadınların dini yaşam pratikleri nasıl değişmiştir?

$\mathrm{Bu}$ çalışmanın hedefi, dindar kadınlar üzerinde yapılan derinlemesine mülakat tekniği ile bu etkileşimin somut sonuçlarını çözümlemektir. Bu bağlamda, dindar kadının, teknoloji ile kurduğu ilişki özellikle dini yaşama tarzında "Bir değişim oluşturmuş mudur?" oluşturmuşsa, "Bu değişim nasıl gerçekleşmiştir?" gibi sorulara cevap aranacaktır. Teknolojik gelişmelerin etkileri üzerinde pek çok çalışma mevcuttur. Dindar kadının yaşam tarzını konu alan çalışmalar da mevcuttur. Fakat spesifik olarak teknolojik gelişmelerin dindar kadınların hayat tarzına ve özellikle de dini hassasiyetlerine etkisini ele alan araştırmaların eksikliği, bu analiz denemesini anlamlı ve orijinal kılabilir. Örneklem, yaşam tarzı değişiminin daha iyi gözlemleyebilmek için değişime dirençli kabul edilen, dini hassasiyeti yüksek, aileden itibaren dini terbiye almış, iyi eğitimli ve orta gelir grubuna ait kadınlar arasından seçilmiştir. Eğitim düzeyi ve gelir durumu ile teknolojiyi kullanma arasında pozitif bir korelasyon olduğu varsayımıyla örneklemin nitelikleri belirlenmiştir.

\section{Teknoloji Kavramı}

'Teknik' kelimesinin (eski Yunanca 'da) sözlük karşıllı̆ı, 'sanat' ve 'beceri' anlamına gelmektedir. Bu arada, 'teknik' ('technic') kelimesinden ayrı olarak, Türkçe 'de yine 'teknik' kelimesi ile karşıladığımız diğer bir kavramdan, 'technique' kavramından söz etmek mümkündür. Birincisinde belli bir hedefi olan, pratik yönü bulunan bir bilgi türü; ikincisinde ise 'sistematik ve karmaşık bir süreç ile bir şeyin başarılması', 'bir etkinlik esnasında ortaya konulan beceri' söz konusudur. 'Teknoloji' kavramı içinde ise artık 'teknik + bilim'in birlikteliği, yani artık salt bir beceri veya uygulamaya yönelik pratik bir bilgi değil de bilimsel çalışmalarla birlikte giden teknik söz konusudur (Ural,2009:5).

Techne kelimesi ile bir şeyi bilmek anlamındaki logia kelimesinin bileşiminden teknoloji (technology) kelimesi oluşmaktadır. Teknoloji kavramının en yaygın kullanımı insan yapımı, doğal olmayan her türlü nesneyi içine alacak kadar geniştir (Kline,2003:210). Teknoloji, insanın maddi çevresini yönetmek ve değiştirmek amaciyla ürettiği araç-gereçlerle, bu sürece ilişkin bilgilerin yöntem ve tekniklerin tümü olarak ifade edilebilir (Acar,1997:346).

"Teknoloji” kavramı ile, bireyin bilimle ilgisini, yaşantısında meydana gelen yaptığı değişiklikleri, dünya görüşündeki değişimleri, toplum ve devlet yapısı üzerindeki etkisini ve özellikle toplumda yol açtığı kültürel değişiklikleri ele alabiliriz. Bu bağlamda teknoloji, gelişiminin her aşamasında, sadece gündelik yaşamın pratik ihtiyaçlarından değil, hayaller, arzular, dinsel motifler gibi insanın bilinçaltında ki etmenlerle de şekillenmektedir. İnsan zihni bu oluşumun yeridir 
(Üşür,2009:7). Başka bir söyleyişle, "teknoloji”" bir kavram olarak, bir yandan nesneleri, aletleri, süreçleri içine alır; diğer yandan da toplumsal ve bireysel değerlerin oluşturduğu bir anlam bulundurur (Ural,2002:2).

Teknoloji yalnızca araç gereçleri ifade etmemekte, bireysel ve toplumsal yaşam üzerine etkiler oluşturmaktadır. Yeni teknolojiler, bilimsel araştırmaların yapılışını etkilediği gibi tüm sanat etkinliklerini, eğitim sistemini, işletme yapılarını ve toplum kültürlerini değişime uğratmaktadır. Teknoloji ile toplum arasında önemli bir ilişki vardır (Aslan,2007:246). Teknoloji yeni bir toplumsal yaşam meydana getirmektedir. Toplumsal olgular da bu yaşam içinde oluşmaktadır. Bu konu ile ilgili olarak İsmet Özel, tekniğin kullanılması ile yaşam tarzının etkilendiğini sadece aletler ve bunları üreten süreçler olmadığını aynı zamanda kültürün ve belirli manevi yapının somutlaşmış biçimi olduğunu söyler. Teknoloji kendisini üreten ihtiyacın kültürünü taşıdığını, teknoloji ile birlikte teknolojiyi üretenin kültürü ve yaşam tarzının da alındığını belirtmektedir (Özel,2015:337).

\subsection{Teknolojinin Tarihsel Gelişimi}

Teknoloji tarihi, teknoloji ve bilimin, günlük yaşam ihtiyaçlarının karşılanmasına ya da insanın maddi çevresini yönetme, şekillendirme ve dönüştürme uğraşıların tarihidir. İnsanı diğer canlılardan ayıran temel özelliklerden biri de alet yapabilmesidir. İnsanın teknoloji üreten bir varlık olması sebebiyle teknoloji tarihi aynı zamanda insanlığın tarihi diyebiliriz (Yörükoğulları,2013:8).

İnsana ait isteklerin tarihi teknoloji tarihine göre daha geniştir. İnsanın ürettiklerinin genişliği hayallerle, özlemlerle, isteklerle ve arzularla dolu insan zihninden kaynaklanmaktadır. İnsana ait kurmaca dünyayı meydana getiren ürünler, sadece ihtiyaçların karşılanmasında görülen problemlere verilen kısıtlı çözümler değillerdir. Aynı zamanda İnsanların kendi ürettiği yaptığı bu ürünler, insanoğlunun kendi varoluşunu tanımlamayı ve sürdürmeyi amaçladığı şekil ve yöntemlerin maddi sonuçlarıdır (Basalla,1996:19).

Teknoloji kültür arasındaki ilişki, birbirini destekleyen ve birbirinden kopmayan bir ilişkidir. Bilim adamlarının kültür sınıflaması yapanken zamanının teknolojik özelliklerini temel alarak, Taş Devri, Bakır Devri, Tunç Devri ve Demir Devri gibi sınıflama yapmaları konuya güzel bir örnektir. Aynı şekilde Sanayi Devrimi, Sanayi Devrimi Sonrası ve Post Endüstriyel Çağ teknolojik gelişmeye paralel olarak yapılan kültürel sinıflamalardır. (Postman,2009:20).

\section{Dindarlık Kavramı}

Dindar dünya görüşü ve yaşam tarzı olarak dini referans alan (Ar. Mütedeyyin) ait olduğu dinin inanç, ilke, uygulama ve sembollerini özümseyen tutum ve davranışlarla bunları gösteren kişidir. Tanrı ile kurulan ilişkiler dindar kişinin bütün dünyevi ilişkilerinin merkezini oluşturur (Kurt, 2009:1-26).

Dindarlık ise, dindar olma, dini yaşama halidir. Dindarlık, kişinin özel hayatında veya kamusal alanda dinî kural ve ritüelleri uygulaması ile görülür (Bilgin, 2003:195-196). Dindarlık, ferdi bir tecrübe olduğu için, kesin bir tanımı yoktur. Daha çok yansımaları göz önünde bulundurularak; 'insanın iman-amel temelinde ortaya koyduğu dini tutum, deneyim ve davranış biçimini yani yaşantıyı veya dindarca hayatı; inanılan dinin emir ve yasakları doğrultusunda yaşamayı ifade eden ve inanç, bilgi, tecrübe, duygu, ibadet, etki, organizasyon gibi boyutları olan bir olgu olarak tanımlanabilir. Bir kimsenin dindar olduğunun vurgulanması, onun dini içselleștirdiği; dinî emir, tavsiye ve yasaklara bireysel düzlemde uyduğu; dini, gündelik hayatında toplumsal denetleyici olarak kabul ettiği ve kendi yaşayışının bir göstergesi haline getirdiği anlamına gelir (Uysal, 2004:85).

\subsection{Dindarlığın Ölçülmesi ve Dindar Kadın}

Toplumda dindarlık olgusu, kişiden kişiye, bir gruptan yahut bir çevreden bir başkasına ve hatta devirden devire önemli değişikliklere ve çeşitlenmeler göstermektedir. Bu durumda, toplumda 
farklı boyutlarda ve şekillerde görülen çeşitli dindarlık yönelimlerinin bilimsel bir anlayış içerisinde nasıl ölçüldüğü ve bu ölçme girişimleri sonucu gözlemlenen dindarlık eğilimlerinin nasıl tipolojileştirildiği konusu ile yüz yüze gelinmektedir (Coştu, 2009:121).

Türkiye'de ilk kez Mehmet Taplamacıoğlu (1962), Türk toplumunun dini hayatını açıklayıcı bir takım dindarlık tipolojileri geliştirilmiştir. Geliştirdiği ölçek Türkiye genelinde dinî hayatın yoğunluğunu tespit içindir. Mehmet Taplamacıŏlu, beşli bir dindarlık tipolojisi ile dini hayatın şiddet ve yoğunluğunu temel almıştır. Bunları 'gar-1 âmil dindarlar', 'idare-i maslahatçı dindarlar', 'dini bütün veya âmil dindarlar', 'sofu dindarlar', 'softa veya yobaz dindarlar' olarak sıralayabiliriz.

Ejder Okumuş ise 'gösterişçi ve samimi dindarlık' şeklinde dindarlığın niteliği, içtenliği ve samimi olup olmadığına göre tipoloji geliştirmiştir (Okumuş, 2006:24). Dindar kadın tanımında ise dindarlık ve cinsiyet vurgusuna değinmek uygun olacaktır. Önemli bir detay kadınların kadın oldukları için veya kadın olarak yaptıklarından ötürü erkeklerden daha dindar olup olmadıkları konusunda ortaya çıkar. Kadınların genel olarak inanç pratikleri ve inandıkları şeylere bağlılıkları hususunda erkeklerden daha bağlı olduklarını gösteren çalışmalar bulunmaktadır (Çoşkun, 2005:113).

Dinselliğin arka planında cinsiyet faktörü kayda değer bir tesir olarak önümüze gelmektedir. Veysel Uysal'ın dindarlık ve cinsiyet faktörünü değerlendiren araştırmasında dinselliğin sosyalleşme derecesini yansıtan Grup ortalama puanları kadınlar lehine daha yüksektir erkeklerin ortalaması $(4,11)$ ile kadınları kadınların ki ise $(4,23)$ dur. İstatistik açısından fark anlamlıdır( $\mathrm{p}<.05)$. Bununla birlikte dindarlık algılamalarında kötü huy olarak tanımlanan tutum ve davranışlar açısından iki cinsin puanları birbirinden farklı değildir. Bu durumda kadınlar dindarlığın sosyal boyutlarına giren tutum ve davranışları erkeklerin algı ve tutumlarına göre daha öndedir (Uysal V., 2006).

\section{Dindar Kadının Yaşam Tarzı}

Bu çalışmanın örneklemi olan dindar kadınları tanımladıktan sonra onların yaşam tarzını ve yaşam tarzı ile neyi kastettiğimizin anlaşılmasını bu yaşam tarzını nelerin etkilediği bilmek önemlidir. Dindar kadının yaşam tarzını hangi faktörler etkiler? Hangi süreçlerden etkilenmişlerdir? Dindar kadın için modernleşme süreci yaşam tarzı dönüşümü için önemlidir. Bu manada yaşam tarzlarını geleneksel ve modern yaşam tarzı üzerinden tartışmak uygun olacaktır.

\subsection{Geleneksel Toplumda Dindar Kadının Yaşam Tarzı}

Yaşam tarzı özelliklerine geleneksel ve modern olarak incelediğimizde geleneksel kadın kimliği geleneksel toplumun ortaya çıkardığı bir kavramdır. Geleneksel toplumlar da gündelik hayatın tamamını dini bir tutumla algılama ve dini bütünlüklü bir alanına bağlı olarak yaşama bu yaşam tarzının vazgeçilmez bir unsuru olarak görülmektedir. Hayatın her alanında zaman algısından, eğlenceye tüketim alışkanlıklarına, manevi deneyimlerden savaş stratejilerin tayinine kadar varan geniş bir düzlemde dinselliğin gücünden cesaret alan bir hayatı kutsallaştırma faaliyeti söz konusudur. Çünkü geleneksel hayatın kendisi bizatihi dinseldir (Subaşı, 2014:319). Dini anlam hayatın bütün alanlarında aile, iktidar ve tüm sosyal münasebetler aynı şekilde dinseli bir anlam ifade etmektedir. Bu anlam insan ilişkilerinden günlük hayattaki tüketimden doğayla olan ilişkilere ölüm ve kader gibi farklı konularda etkisini gösteren bir anlayışa işaret etmektedir (Coşkun, 2005:332). Geleneksel toplumlarda dönüşüm yavaştır ve bu tür toplumlarda hızlı değişimler beklenmez. Geleneksel toplum toplumsal, kurumsal ve kanuni olarak değişime karşı yapılandırılmıştır. Bu bağlamda geleneksel kadın kimliğinden anladığımız geleneksel toplumun bir parçası olan değişime açık olmayan, hızlı değişmeyen, kutsal kabul ettiğini benimseyen ve kendisinden sonra gelen nesle aktarma sorumluluğunda hisseden kadının kimliğidir (Metin, 2010:74-92). 


\subsection{Modern Toplumda Dindar Kadının Yaşam Tarzı}

Modernleşmenin oluşturduğu zihniyet içerisinde en sorunlu alanlardan biri de yeniden inşa edilen kadın söylemleri ve kadına bakış açısı olmuştur. Modernleşmeyi batılılaşma olarak algılayan yan Türkiye de batılı yaşam tarzını oluşturamamanın en önemli nedenlerinden biri olarak geleneksel kadın modeli görülmüştür. Bu bağlamda modernleşme süreci kadın konusunun gündelik hayatta kadının değişimi ile bir görülmüştür.

Tanzimat'la birlikte yeni yaşam tarzı öncüleri kadınların Batı orjinli medeniyet dönüşümü, hızlanmıştır. II. Meşrutiyet döneminde Kadınların çalışarak toplumsal hayata katılması gerekliliği, toplumsal geleceğin kadınların değişmesine bağlı olduğu, kadının medeniyetin ölçüsü olduğu, modernleşmenin kadın özgürlüğünden geçtiği düşüncesi ifade edilmiştir. Bu dönemde kadının daha fazla kamusal alana dahil olmasının, kentsel mekânlara çıkmasının toplumsal görünürlük oluşturmasının önemsendiği bir hale gelmiştir. Kentli kadınlar hem kıyafet değişimi hem de toplumsal düzeyde görünürlük kazanarak mahrem alandan çıkmaktadır. (Göle,2010:70). Türkiye'de Altmışlı ve yetmişli yıllardan itibar "İslam' da Kadın" mevzu altında İslamiyet'te kadının yerinin ne olduğunu ortaya koymaya uğraşan bir fikir ve yazın cereyanı oluşmuştur. Dindar camiada 'İslam'da Kadın' anlayışı genellikle Mısır ve Hint yarımadası orjinli çevirilerden kaynaklanarak meydana gelmeye başlamıştır. İşte bu bağlamda o dönemde yayınlanan popüler kitaplar, modern kadın tipolojisini eleştirerek, kadınların annelik ve eğiticilik rolüne, anne olarak eğitimli olması gerekliliğine vurgu yapmıştır (Şişman, 2015: 97). Bu etkileşimle 80’lere kadar özel alanda olan kadın, İslamcılar ve geleneksel dindar için yüceltilmiş, evinde oturup kocasına hizmet eden çalışmayan kadın modeli dindar kadın modeli olarak görülmüştür (Tekin, 2004:217).

1970'li ve 1980'li yıllarda feminizm de İslamcı yazınında tartışılmaya başlanmıştır. 1980'li yıllarda sayıca çoğalan İslamcı dergilerde feminizm batılı kadının hak arayışı olarak sunulmuştur. $\mathrm{Bu}$ dergilere göre İslam kadınlara haklarını verdiğine göre Müslüman kadının feminizm gibi bir problemi o yoktur düşüncesi hâkimdir. Dindar olmaları sebebiyle 90'lı yıllarda cezalandırılanlar hem erkekler hem de kadınlar olmasına rağmen, başörtüsü yasaklarının, kadınlar üzerinde görünür olmasıyla İslam ve kadın hakları konusu önemli bir dönüşüm geçirmiştir. Dindar kadınların duruşu başörtüsü yasaklarının baskısı ve diğer taraftan yasakları aşmak üzere geliştirilen dilde seküler delillerin öne çıkması ile kırılmaya uğratmıştır. Bu süreçte kadınların erkeklere ve giderek kadınların kadınlara bakışında bir ötekileştirme süreci oluşmuştur (Barbarasoğlu, 2013: 57).

2000'li yıllarla birlikte dikkatten kaçmaması gereken en önemli süreç, dindarların yeni yaşam tarzları ile bütünleşmesini sağlayan dinamik faktör ekonomi ve politikadır. Dindarların ekonomik liberalizmle tanışmasıyla aynı oranda ona has kültürel kabulleri de beraberinde getirmiştir. Özellikle iktidar olmanın verdiği güven de modernleşmenin nasıl gerçekleşeceği konusunda muhafazakârlık alternatif bir yaşam tarzı olarak görünmeye başlamıştır. Neticede Muhafazakârlar burjuva medeniyetine politik ve ekonomik anlamda da teslim olmuşlardır. Modern dünyanın para politikalarına eklemlenen muhafazakârlar, bu durumun getirisi olan sosyal ve toplumsal pratikleri de benimsemiştir. Kısaca Dindar insanlar ekonomik ve politik olarak geliştikçe yaşam tarzları da değişmiştir (Yücebaş, 2012:62-80).

\section{Araştırmanın Çalışma Grubu}

Araştırma evreni Türkiye'de kendisini muhafazakâr tanımlayan, yüksek öğrenim görmüş, teknoloji kullanan Bursa' da yaşayan 18 kadındır. Çalışma grubunun tamamı Bursa kent merkezinde yaşayan, orta ve yüksek gelirli, başörtülü, muhafazakâr ailelerde yetişmiş, dini eğitim almış, meslekleri olan,1969-1990 yılları arası doğumlu, özellikle evli ve çocuklu kadınlardır.

\section{1.Örneklemin Nitelikleri}

$\mathrm{Bu}$ çalı̧̧manın hedef kitlesi dini eğitim almış, özel hayatında dini hassasiyeti olduğunu belirten ve eğitimli sosyal ve evli kadınlardır. Teknoloji ulaşabilme imkânı yüksek olması sebebiyle 
orta-orta üst tabaka gelirli, eğitimli kadınlar seçilmiştir. Geleneksel ve modern ayırımını görebilmek için katılımcıların anne-babalarını da dindar olarak tanımlamalarına dikkat edilmiştir. Böylelikle katılımcıların da dini donanım ve eğitim almış olmalarına dikkat edilmiştir Türkiye de dini yaşantı araştırma sonuçları (Türkiye'de Dini Hayat Araştırması,2014:106) dikkate alınarak başörtülü kadınların dinini yaşama hassasiyetleri göz önünde dini yaşama hassasiyetleri bulundurulmuş ve örneklemin tamamı başörtülü kadınlar seçilmiştir.

Katılımcıların hemen, hemen bütün meslek gruplarında dağılımları mevcuttur. Örneklemimizde ki tüm kadınlar sosyal yönleri güçlü kadınlardır. Katılımcıların, \%15(3) kişi öğretmen, \%15(3) kuran kursu öğretmeni, \%10(2) araştırma görevlisi, \%10(2) yönetici, \%5(1) doktor, \%5(1) avukat, \%5(1) endüstri mühendisi, \%5(1) memur, \%15(3) ev hanımı olarak şekillenmektedir. Ev hanımlarının çalışmama nedenleri eşlerinin gelir düzeylerinin yüksek olmasıdır. Bunların \%10(2)si STK'lar da aktif çalışmakta, \%5(1) ak parti il yönetim kurulu üyesidir.

Katılımcılar \%44‘i (8 kişi) babalarını namaz kılan muhafazakâr, \%5’i (1 kişi) hafız, \%11’i (2kişi) ehli tarik, \%21'sı (4kişi) imam olarak tanımladı. Katılımcılardan \%5'i (1 kişi) ailesinin geleneksel dindar olduğunu vurgulamış, \%55 (9 kişi) ailesinin dini hassasiyet düzeyinin yüksek olduğu ifade etmiştir. Katılımcıların \%38'i (7 kişi) ailelerinin din eğitimini katı ve baskıcı buluyor. Baskıcı bulanların ortak kanaatleri ailelerin tutumlarının zamanla değişim göstermesidir

Ailelerin çoğunluğu \%50’i (9kişi) çocukların dini eğitimi almaları için İHL okullarını, \%11(2) kişi bulundukları ilde İHL olmadığı için kız meslek liselerini tercih etmiş̦tir. \%28 (5)kişi düz liseye göndermiş, ailelerin \%11'i (2 kişi), çocuklarının daha iyi bir din eğitimi almaları için medrese eğitimini uygun görmüşlerdir. Katılımcıların bir tanesi hafızdır. İHL' ne gidenlerin ortak kanaatleri ailelerin baskıcı tutumlarının oluşturduğu dine karşı oluşan ön yargının bu lise hayatından sonra kalmadığını ve dini hayatlarını daha çok içselleştirdiklerini ifade etmişlerdir.

Katılımcıların tamamı üniversite mezunu orta ve yüksek gelir grubuna girmektedir. Deneklerimizin \%30(6)kişi ilahiyat mezunu dur. Katılımcıların tamamı 28 Şubat mağduru dur.

Bu çalışmanın örneklemi başörtülü kadınlar, 1969-1990 yılları arasında doğanlar şeklinde belirlenmiştir. Katılımcıların \%5(1) kişi 25-30 yaş arası , \%40(7) kişi 30-35yaş arası, \%10(2) kişi 35-40 yaş arası, \%40(7) kişi 40-45 yaş arası, \%5(1) kişi 45 yaş üzerindedir. Türkiye'deki 1970'li yıllardan sonra meydan gelen ekonomik-teknolojik gelişmelerin hızlanması dolayısıyla bu yaş grupları seçilmiştir. Bu yaş grubu bir önceki dönemi de gözlemleyebildiği için hayat tarzındaki sosyal değişmeyi daha iyi ortaya koyabilmektedirler.1970'li, y1llarda, ekonomi de meydana gelen değişimle başlayan 1980'li yıllarda artan iletişim teknolojisi ve beraberindeki, siyasal ekonomik değişiklikler toplumun sosyo-kültürel yapısını değiştirmiştir. (Okutan,2013, s.15)

\subsection{Yöntem}

Çalışma nitel araştırma tekniklerinden yapılandırılmış görüşme ya da etnografik görüşme olarak da adlandırılan derinlemesine görüşme tekniğiyle, gerçekleştirilmiştir. Zincirleme örneklem seçim tekniği olarak da adlandırılan kartopu örneklem seçim tekniği kullanılarak katılımcılara ulaşılmıştır. Yarı yapılandırılmış görüşme yapılmıştır. Görüşmeleri gerçekleştirmek için tüm görüşmelerde kullanılmak üzere bir dizi soru hazırlanmıştır, görüşülen kişinin soruları istediği ayrıntıda yanıtlamasına izin verilmiş ve görüşmeci gerektiğinde görüşülen kişiye sorularla ilgili açıklamalar yapılmıştır. Kişilere sınırlı bir esneklik sağlayarak sorular yeniden düzenlenmiştir. Derinlemesine mülakatla, bireyin, duygu, düşünce dünyasını anlatan, fikirlerini, tecrübelerini paylaşmaya firsat sunan yüzünün yanı sıra, öznenin jest ve mimiklerinden giyim tarzına ve kullandığı eşyalara kadar yaşam tarzı görselleşmekte, bir bakıma zihin dünyasını yansıtan cümlelerinin arka planı duruşuyla karşılaştırılmaktadır (Okutan,2013, s.18).

Araştırma problemine ilişkin yüzeysel bilgilerden çok kişilerin düşünce görüş ve deneyimleriyle ilgili bilgi toplayarak, az sayıda insanla görüşülerek katılımcıların deneyimleri 
görüşleri düşünceleri inançları hakkında çok detaylı bilgi elde edilmeye çalışılmıştır. Günlük hayattaki teknolojiyi nasıl kullandıkları temalar çerçevesinde çıkarılan anlamlar yoluyla sorgulanmıştır. $\mathrm{Bu}$ nedenle çalışmada nitel araştırma desenlerinden görüngübilim (fenomenoloji) yaklaşımı kullanılmıştır. Görüngübilim deseni, bireylerin gündelik yaşantılarından yola çıkarak bilinçli deneyimler üzerine odaklanır ve deneyimlerin bu bireyler tarafından nasıl anlamlandırıldığını ortaya çıkarmak için kullanılır. Deneyimlerin bazı popüler inançlardan, basmakalıp örneklerden ya da akademik kuramlardan çıkıp çıkmaması önemli değildir; önemli olan kendi kendini bilen ve bilinçli bir biçimde, durumu, "aykırrı" ya da "olağanüstü" olarak inşa etmek için var olan bilgiden yararlanılmasında sosyal durumun özelliğini vurgulamaktır (Burawoy, 1991) Görüngübilim deseninde, insanların benzer yaşantıları algılamaları ve yorumlamalarındaki ortaklıklar bulunmaya çalışılır. Bu ortaklıklar, deneyimlerin özü biçiminde ifade edilebilir (Fraenkel \& Wallen, 2006). Diğer bir ifadeyle, görüngübilimin desen olarak kullanıldığı bir çalışmada, deneyimin değişkenlik göstermeyen özü ortaya çıkarılır. Burada "öz", deneyimin kişilerarasında ortaklaşan noktalarına gönderme yapmaktadır (Patton, 2002). Bu bağlamda, bu çalışmada muhafazakâr kadınların farklı teknoloji aletlerinin kullanımının farklı deneyimlerin ortaklaşan noktalarına ulaşılmaya çalışılmıştır.

Örneklemin sınırlılığı ve sayısına gelince derinlemesine mülakat gibi zaman alan bir araştırma tekniğinde küçük örneklem grupları seçilmektedir. Veri toplama yapılırken aynı zaman da veri analiz de yapılmış katılımcılardan aynı cevapların alınmaya başlamasıyla teorik doyma noktasına ulaşılmış ve 18 kişiyle yapılan mülakatlar doyurucu kabul edilmiştir.

Yüz yüze görüşmeler genellikle katılımcıların evlerinde yapılmış, yaşam tarzı ile ilgili izlenimler not edilmiştir. Ses kaydı ile yapılan görüşmelerin gizli olacağı ilkesi katılımcıların her türlü sorulara rahatlıkla cevap vermesini sağlamıştır.

\section{Bulgular}

\subsection{Dini Bilgiyi Öğrenme, Öğretme, Yaşama Kolaylığı}

Teknolojinin gelişmesi dinin geleneksel öğrenme, öğretme ve dini yaşama şekillerinde değişme meydana getirmiştir. Eskiden Kur'an-1 Kerim'i öğretme sadece bir hoca nezaretinde öğrenebilirken şimdilerde Kur'an-1 Kerim'i öğretme programları aracılığı ile sanal ortamdan da destekle öğretme yapılabilmektedir. Bu durumun hocanın direkt otoritesinden yoksun olması sebebiyle eskiden mevcut olan öğrenme korkusunun şimdilerde olmadığı vurgusu yapılmaktadır. Bunun yanında önceden mukabele dinlemek yine birebir hocayı dinlemekle gerçekleşirken şimdilerde özel bir ortam ihtiyacı duymadan yine kayıttan dinleyerek mukabele gerçekleştirmek mümkün olmaktadır. Ayrıca hafız olmak için uygulanan hafizlığın geleneksel metoduna alternatif olarak internet üzerinden yapılan hafızlık çalışmaları da görülmektedir. Ayrıca dinin içreğine ait öğrenmeler de ise artık sanal ortamda çok fazla bilgiye ulaşma imkânı tek kaynaklı daha otoriter bilgi ve fetvalar yerine çoğulcu bir anlayış geliştirmiştir. Eskiden dini herhangi bir konu hazırlamak için çok sayıda kitapları taramak ve incelemek gerekirken şimdilerde arama motorları sayesinde aranan bilgi her ne ise herhangi bir kitabın kendisine gerek duymadan tüm ayrıntılarla isteyen kişinin önüne gelmektedir. Bununla birlikte akıllı telefonlarda bulunan namaz vakitleri ve ezan programlar da dindar kadınlar tarafından kullanılmaktadır. Tüm bu durumlar dini bilgilerin ve fetvaların güncellemesini gerektirmektedir. Eskiden Mushaf abdestsiz tutulmazken besmelesiz açılmazken, şimdilerde kuran okuyan kalemler ya da ekranına kuranı kerim aktarılan Ipad, laptop ya da akıllı telefonları açarken ya da dokunurken durum ne olacaktır? Ayrıca kuranı kerimi sanal ortamda dinlemekle birebir dinlemek aynı mıdır? Tüm bu verilerin 1şığında şu saptama önemlidir; eskiden dini yaşamak için olmazsa olmaz dinin kurumsal (cami, hoca, cemaat, Mushaf) araçlarına şimdilerde çok ihtiyaç duyulmadan dini ritüeller yaşanabilmektedir. Dini yaşama daha öznel bir alana taşınmaktadır. 


\subsubsection{Dini Öğretme, Öğrenme}

Katımcı12 Kur'an-1 Kerim'i öğretirken projeksiyon cihazına yansıtılan Kur'an programlarını Kur'an eğitimin de yardımcı olarak görmektedir.

Projeksiyon kullaniyoruz. Benden daha fazla ve etkin kullanan arkadaşlarım da var. Ben çok etkin kullanmıyorum henüz. Fakat faydası olduğunu düşünüyorum. Bilgisayarlı eğitimin Kuranı kerim eğitiminde de din eğitiminde de faydast oluyor zaman, zaman ama tamamen bilgisayar ve slâyt'a bırakmak da iyi olmaz çünkü kuranı kerim uygulama isteyen bir derstir. Dini bilgiler derslerinde ișe yarıyor bilgi yarışmaları oluyor değişik eğlenceli renkli ya da slâytlar oluyor onlar faydalı oluyor. (K12)

Katılımc19 Kur'an öğretme setleri ve Kur'an okuyan kalemlerin çocukların eli sopalı hocalardan kurtuluşu olarak yorumlamaktadır.

Çocuklar için kuran ögretme setleri var. Sesli kuran okuyan, kalemi tutarak kuranı harf, harf okuyor. Bence çok önemli eski sopayla döven hocalar yok artık yani, Sanal âlemin dine ne kadar katkı sağladığı tartışılır. Anne çocuğunu yetiştirirken oradan öğrenebilir. Görme engelliler için sesli kitaplar var. (K 9)

Katılımc12 eşinin hafızlığını internet üzerinden gerçekleştirdiğini söylemiştir.

Teknolojiyi nasıl kullandı̆̆ınız önemli mesela eşim hafızlı̆̆ını internet üzerinden yapıyor. (K 2)

Katılımc19 dini herhangi bir fetva için internetten yararlandığını belirtmektedir.

Bir şeyin caiz olup olmadı̆̆ın internet ya da telefon aracıllğ ile diyanetten fetva alırım. Bazen ama fikı konusunda diyanet işlerinden açıp bakıyorum. Şu nasılmış bazı şeriat kurallarını bakıyoruz. Internet yararlı bir şey internete asla zararlı demiyorum. (K9)

Katılımcı1 birebir iletişimle Hoca Efendilerin yaptığı yüz yüze yapılan vaazların yerine televizyondan yapılan vaazların popülerliğine dikkat çekmiştir.

Teknoloji dinin geleneğini değiştirdi, artık vaazlar televizyonda. Eskiden hocalarla direk iletiş̧im söz konusuydu.(KI)

Katılımcı11 TV de ki farklı hocalardan dini bilgi almanın katı bir dini anlayışı değiştirdiğini, söylemektedir.

Kayınvalidem eskiden tek kaynaktan sohbet dinliyordu. Tek bir yerin sohbetlerine gidiyordu oradaki hoca hanımların dediklerini uyguluyordu, kanun gibi kabul ediyordu. Dini tek kaynaktan ögrenmeye çalışıyordu ama şimdi teknolojinin de çok gelişmesi ile TV de farklı kanallar farklı hocaların da farklı şekilde gerçekte Kuran'a uygun radyolarda ayn şekilde sünnete dayanarak farkl yönleri göstermeleri ile kayınvalidemin ufku genişledi diyebilirim. Yani artık çoktan seçmeli düşünüyor. Eski si gibi tek bakış değil, at gözlü̈̆̈̈ değil, şimdi her tarafa bakarak düşünüyor. Karşı tarafin penceresine de bakarak düşünüyor artik.(K11)

Katılımcı5, herhangi bir ayeti araştırdığında, dini bilgilere farklı yorumlarla ulaşma imkânının internet üzerinden yaptığını söylemektedir.

Diyelim bir konuda bir ayete ihtiyactm var. Ayet yazlyorum lokma suresi ayeti Google'dan geliyor. Farklı siteler var aynı ayetin 20-25 tane bilim adamı ya da tefsirci tarafindan yazılmıs yorumları bir anda elime geliyor bu ben benim hoşuma gidiyor. Aynı ayete 28 ayrı gözün bakmasından keyif alyorum ben de 29. Oluyorum. (K5)

Katılımcı16 eskiden bir konuda bilgi sahibi olmanın araştırma yapmanın çok zaman aldığını şimdi bunu tek tuşla yapabildiğini aktarmıştır.

Bilgiye ulaşma alanında çok büyük kolaylık sağladı. Dini konularda eskiden çok fikıh ve siyer karıştırırken şimdi tek tuşla güvenilir siteleri bularak ulaşabiliyorsun o bilgiye o rahatlığı oldu zaman kazandırd diyebilirim. (K16) 
Katılımcı2 teknolojinin irşad faaliyetlerini artırdığını ifade etmiştir.

Allah istemeseydi teknoloji hiç gelişmezdi. Hayra ve şerre kullanmak insanlarla alakal. Sosyal medyadan takiplerimi paylaşımı ve iletişimi artırdı. Teknoloji sayesinde irşat çalışmaları mümkün. (K2)

\subsection{2.İbadet Etme Kolaylığı}

Katılımcı16 babasının kullandığı kuran okuyan kalemlerin Kur'an taşımak zorunda kalmadan farklı kıraatlerden, farklı hafizlardan istenildiğinde mealini de dinleyebileceğiniz Kuran okuma ve dinleme kolaylığına, vurgu yapmıştır.

Dini yaşantıya kolayllğı var, mesela sesli kuran okuyan kalem var. Babam kullanıyor istediğin hafizı seçiyorsun. İstediğin hizl ayarllyorsun ister mealli, ister mealsiz. Bir karton var orda sure isimleri var onu taşıldığın zaman kur an taşımana da gerek yok. İstersen bakarayı okusun sana. Külliyatları falan yerleştiriyor cep telefonuna hatmi indiriyor cep telefonuna bunlar da var eskiye nazaran çok güzel kolayllk ve imkânlar var. Babam arkadaşlart ile bir araya geldiğinde kalemi getiriyorlar. Hadi bir rahman suresini dinleyelim, baslyorlar onu tutuyorlar başllyor istediği hafizdan okumaya.( K16)

Katılımcı2 telefonlardaki namaz vakitlerine ayarlı ezan programlarının katkısını dile getirmiştir.

Akıll telefonlarda ki ezan ve dini program uygulamaları çok etkili.(K2)

Katılımc19 Ramazan Ayında radyodan dinleyerek mukabele yaptığını zikirmatikle zikir çekmenin kolaylığını dile getirmiştir.

Mesela zikirmatik çıkt çok avantajl bir şey, saymıyorsun. Bir keresinde de radyoda dinleyerek ramazan da hatim yaptım. Bu sana aynı tatmini verdi. Hoca orda gayet düzgün okuyor.(K9)

Teknolojinin dini yaşama katkısını Allah'ın yardımı olarak yorumlayan avukat katılımeı internet aracılığ 1 ile sosyal medyanın paylaşımı, insanlar arası iletişimi artırdığını,

Katılımc112 ibadetlerin, teknolojinin dini bilgilenmeyi artırdığını bu çok bilgilenme ile ibadetlerin daha bilinçli yapıldığını gelenek ve dinin artık birbirine karıştırılmadığına söylemekle birlikte insanların bu imkânın ibadetlerde kendilere özel kolaylık bulmasıyla dini hassasiyetlerin kaybolduğunu da söylemeden geçmemiştir.

Tabi ki önceki hacla şimdiki aynı değildi. Ama eskiden daha bilgisizlerdi. Bizde gelenek ve din birbirine çok karışmış. Ama bu teknoloji ile çok bilginin çıkması ve paylaşılması ile insanlar bilinçlendi ama kolaylıklarına kaçan da oldu (K12)

Katılımc116 teknolojiyi bilinçli kullanabilenler için Allah'ın lütfu olarak görmekte onun sağladığı zamanı ibadetle geçirilebileceğini ifade etmektedir.

Hayatımıza getirdiği kolaylıklar olarak düşünüyorum bulaşık makinesi olsun, çamaşır makinesi olsun, kurutma makinesine kadar her şey var. Eskiden cep tel yoktu. Simdi hayatımızın her anında bunlar bize Allah'ın lütfu iyi kullandığın zaman. Insan bilinçli olursa bunlardan doğru şekilde faydalanabilir. (K16)

\subsection{Dini Yaşam Geleneğinin Değişmesi}

Dindar kadınların teknoloji ile yoğun uğraşları ile yeni dini yaşam hassasiyetleri çıkmıştır. Geleneksel dindar kadınlar için mahremiyet alanı çok keskin iken teknoloji ile kaynaşan dindar kadın için mahremiyet alanı değişmiştir. Kamusal alana çıkarken kendine sınırlar çizen ya da evine gelen yabancılar için belli sınırlar koyan dindar kadın sanal ortamda kendisi evi ile ilgili sınırlar koymamaktadır. Geleneksel dindar kadın fotoğrafla bile arasına mesafe koyarken modern dindar kadın görüntülü aktarım ve paylaşımları sanal kabul etmektedir. Sanal olan da günah kavramı içine girmemektedir. Bununla birlikte dinin günah saydığı bir kişinin aleyhinde konuşmak, sanal ortamda rahatsızlık vermemektedir. Yine başka bir kişiye ait bir şeyi izinsiz almak olan hırsılılk büyük 
günahken sanal ortamda özellikle kişiye ait bilgilerin vs. alınması yine kişilerde rahatsızlı vermemekte günah hissi uyandırmamaktadır. Bununla birlikte sanal ortamda sahih bilgi araştırması daha az yapılmakta sanla ortam bilgisi sorgulanmadan uygulanmaktadır.

\subsubsection{Günah Algısının Değişimimimi}

Değişen kavramlara baktığımız da özellikle günah algısının değişimi dikkati çekmektedir Katılımcı11 eskiden kayınvalidesinin fotoğraf çekmeyi bile haram görürken şimdi televizyon başından kalkmadığını söylemektedir.

Biz evlendiğimizde eşim ailesi pek çok konuda katı idi. fotoğraf çektirmek bile kayınvalidem çok ayıp görüyordu günah görüyordu haram görüyordu düğün fotoğrafi çektiremedik benim düğünümde eşimle birlikte fotoğrafim yoktur. Eskiden internet TV yok zaten evlerinde de seyretmezlerdi. Radyo bile çok dinlenmezdi ama şimdi herkes her şeyden anında haberdar. Anında her şey elinin altında kayınvalidem eskiden TV günah derdi TV seyretmezdi hatta babama TV seyrediyor diye -senin baban da dindar mı? Demişti. Fakat şimdi benim kayınvalidem 20 sen sonra sabahlara kadar TV seyrediyor tartışma programları haberler ve bana anlatıyor. (K11)

Katılımc113 babasının önceden televizyon olan odaya girmediğini ama şimdiler de iyi bir TV izleyicisi olduğunu anlatmaktadır.

Babam Almanya; da iken peygamberimizi rüyasında görmüş arkası dönük görmüss. Kalkınca televizyon var diye peygamberimiz yüzünü dönmedi dedi. Şimdi yaşlandı artık Cüneyt Arkın'nın bütün filmlerini tekrar, tekrar izledi. Ama yine kötü şeylere bakmiyor.(K13)

Katılımcı11 eskiden çocuk bezi ve tuvalet kâğıdı gibi şeylerin kullanılmasının sorgulandığını haram sayıldığını şimdilerde ise ihtiyaç görüldüğünü anlatmaktadır.

Ben çocuk bezi kullandığımda o zaman çok yaygın değildi. Görümcem -ben ölsem dahi, dünya kadar zenginde olsam bu bezi kullanmam günah bunlar israf tek kullanımlık kullanılıp atılıyor demişti. Ama benden iki sene sonra doğum yaptı o kullandı. (K11)

Katılımc15 bu konuda, şimdi şeytanın özellikle cep telefonu ve bilgisayar aracılığı ile musallat olduğunu ve özellikle bu aletleri kullanırken Euzu-Besmele çekmek gerektiğine vurgu yapmıştır.

Şimdi burada Euzu-Besmeleyi pratik hayatta doğru kullanmadığımızı düşünüyorum. Sanki EuzuBesmele tek Kuran-ı Kerim okumaya başlarken çekilir gibi ama şeytan her yerde ve bana musallatsa cep telefonu ve bilgisayar ilişkimde de çok önemli. Şimdi başka bir sıkintt yaşıyorum. Kendi kendime Euzu-Besmele çekerek bilgisayarın düğmesini bastı̆̆ımda bilgisayarın bana daha çok hizmet ettiğini düşünüyorum.(K5)

Katılım3 ve katılımc111 özellikle sosyal medyayı büyük bir dedikodu ve fitne aracı olarak tanımlamakta buradaki bilgilerin sorgulanmaması neticesinde her türlü yalanın çok çabuk hakikat olduğunu söylemektedir.

Sosyal medya da medya kahramanlı̆̆ yapllyyor. Gündelik hayatta insanlar birbirlerine söyleyemeyecekleri şeyleri orda çok rahat söylüyorlar. Yalan orda çok çabuk hakikat oluyor yaylliyor. Ĕ̈itimli insanlar bile haberin aslını doğru mu değil mi diye araştırmıyor. Hemen paylaşıyorlar. Çoğu zaman provokasyonlara çok açık bir ortam. (K3)

Tehlikeli buluyorum. Güvenilir de bulmuyorum. Insanlar doğruluğundan emin olmadlklarl şeylere inanıyorlar. Kimse doğru olup olmadı̆̆ın araştırmadan iftira ve hakaretler söz konusu oluyor. Fitne aracı insanları çok rahat karalyyor. Özel ya da mahrem yok.(K11)

Katılımc15 sanal olanın günah kabul edilmediğini normal hayatta yapmayan Müslümanların internet üzerinden kumar oynadığını, porno izlediğini anlatmaktadır.

Bir kısım insan ciddi manada porno izliyor. Bir kısım insan internet üzerinde kumar oynuyor. Bir kısım insan bilgisayar oyunlarına ciddi manada bağımlı benim çok yakın akrabam var okey oynuyor, 
çanak kırıyor. Beraber tatile kaplıcaya gittik. "Şu an çanak kıracă̆ım” diye, kaplıcaya gitme nedenimiz olan havuza girmeye gelemedi. Namazı kllyyor abdesti ile oturuyor. Namaz kıllyor huzura çıkıyor oynuyor. Diyor ki, "para dönmüyor ki" deyip mutlu oluyor "para dönmüyor, kumar değil" diyor kendine .(K5)

Katılımcı5 kadın aldatmalarının bilgisayar üzerinden daha fazla yapıldığını sanal olanın günah sayılmadığını ifade etmiştir.

Ciddi manada kadın aldatması var. Yani kocasını bilgisayar başında aldatan senin benim gibi kadın sayısı tavan yapmış bir din görevlisi arkadaşım bir vakadan bahsetti "euzubillahimineşşaytanirracim” 72 yaşında bir teyze eşi ölmüş 15 sene önce. Yatsı namazını kılıp oğullarının falan olduğu yerde geçiyormuş bilgisayarın başına birine 18 yaşııda birine 22 yaşında tanıtmış kendini chat odasında iki kişiyle konuşuyor. Ana etme eyleme, ne var diyormuş saçımın kılını gören mi var, elime dokunan mı var şu dünyadan geldim gidiyorum bir tane güzel. Laf duymadım babanızdan, bana güzel, güzel şeyler söylüyorlar. Şimdi bu ihtiyaç o kadar çok kadın da var ki o kadar çok insanda var ki.(K5)

Katılımcı17 teknolojinin insanın günaha girme imkânını artırdığını anlatmaktadır.

Çıplaklık baklşlarımız ister istemez zinaya karışabiliyor gözlerimiz nereye baksan sıkıntı. TV'yi açtı̆ııı zaman o bile yeter sokağa çıkmamıza gerek yok. (K17)

Katılımc115 artık bidat ve hurafelerin teknoloji sayesinde boyut değiştirdiğine dikkat çekmektedir.

Facebook'ta çok saçma şeyler dönüyor. Mesela diyor ki Peygamberimizin ayak izini paylaşıyor beğenmeyenler şöyle olsun. Kandil de hat paylaşıyor beğenmeyenler şöyle olsun. Bir dua yazlyor sen göz alışkanliğı okuyorsun refleks olarak. Bunu sana okutabilmek için paylaşıyor. Sanırım bir amacı en azından okutabilirim ya da tevhit yazlyor paylaşıyor. Sen onu okuyunca onu söylemis oluyorsun. Böyle bir amaçla paylaşlyorlar. Çok beğeni alma. Twitter'da hashtag olayl dünyada Türkiye'de birinci oluyorsun. En çok tweet atıllp paylaşılan şey. Cami fotosunun birinci olması ses getireceğini düşünüyorlar.(K15)

Katılımc115 normalde evinin içinin görülmesinde rahatsız olacak bayanların sosyal medya üzerinden yatak odalarını dahi paylaştıklarını dışarıda el ele yürümekten çekinen eşlerin sosyal medyada yanak yanağa fotoğraflar paylaştığına dikkat çekmektedir.

Mahremiyet alanları değişti. Kapalı eş aile ortamının fotosunu çekiyor koyuyor. Bizim aile mahremdir gösterilmez artık yok. Türbanlı eşiyle yanak yanağa fotosunu koyuyor. Ya da ev halini koyuyor bunlar geleneksel kodlara karşı şeyler mahremiyeti kirlcı şeyler .(K15)

Katılımcı15 ayrıca internet üzerinden çalınan bilginin hırsızlık gibi algılanmadığını Müslümanların bunu rahatllkla yapabildiklerini söylemektedir.

Mesela öğrenci yazacağı makaleyi internetten kopyala yapıştır yaptyor. Eskiden böyle bir şey yapılamıyordu. Müslüman insanlarda bunu yapıyor. Çalmak suç ama bilgi hırsızlı̆̆ı yapıllyor.(K15)

Katılımcı7 insanın sürekli teknoloji kullanarak kendisinin yaşama bir emek katmadığını ve kendi yaşantısına yabancılaşıtığını söylemektedir.

Ben 15 yaş dönemime baktığımızda çamaşır makinesi vardı bol su istiyor diye kullanmıyorduk. Biz o zaman işe yardı̆̆ımızı hissediyorduk. Üretiyorduk zaman bereketli idi. yaptı̆̆ımız işten mutluluk duyuyorduk. Sende bir şeyler için çabalıyorsun ürettiğini düşünüyorsun ama şimdi birileri benim için bir şeyler üretti ürettiği şeyler benim işimi hallediyor. Ben o esnada ne yapıyorum. Görev insanın kendisine düşüyor. Hayatımı kolaylaştırıyor ama benim de üretecek bir şeylerimin olması lazım.(K7) 


\subsubsection{Değerlerin Değişimi}

\section{İnfak}

Teknoloji gelişiminin getirdiği üretim hızı tüketimi de beraberinde getirmiştir. Dini yaşam tarzını benimseyen kadınlar sürekli üretilen, daha yeni model ürünleri alma duygusu ve bir dini değer olarak israf etmeme duygusu arasında çelişki yaşamaktadırlar. Dini yaşam tarzını benimseyen kadınlar bu çelişkiyi, modeli daha eski eşyaları vermek şeklinde çözüm üretmişlerdir. Böylelikle hem yeni bir şey alma imkânı hem de daha eski olanı vererek infak etmiş olma duygusu yaşanmaktadırlar. Katılımcılar için önceden infak etmek eskiden en sevdikleri şeyleri vermek demekken şimdilerde yeni şeylere yer açmak için eskileri vermek şekline dönüşmüştür.

Katılımcı1 yeni teknoloji almasının eski olanı vermeye vesile olduğunu söylenmektedir.

Yeni teknolojileri değiştirim ama eski olanın da değerlenecek yerini bulurum. (K1)

Katılımcı2 eskiyen teknolojiye ait kullandığı şeyleri vererek kendisine daha üst teknoloji alabildiğini belirtmektedir.

Bazen eskisini ögrenci evine verip kendime daha üst bir şey aldiğım oluyor. (K2)

Katılımcı3 kullanmadığı eşyaları verdiğini ifade etmektedir.

Giymediğim klyafeti de sevgi market vs. yerlere veriyorum. (K3)

\section{Sabir}

Teknoloji gelişimi getirdiği gelişimlerden bir tanesi de istenilen şeye hızla ulaşma imkanıdır. Yeni gelişen teknolojinin ulaşma hızı bir önceki teknolojinin ulaşma hızına göre daha ileri gitmektedir. Katılımcılarımıza göre bu istenilen şeye ulaşmak için beklemenin olmaması sabır davranıșı azaltmaktadır.

Katılımcı3 sanal olandaki hızın gerçek hayatta da böyle bir beklenti oluşturduğunu bunu elde edemeyen insanların ise çok hoşgörüsüz ve öfkeli olduğunu ifade etmektedir.

Sabırsızlığımızı artırlyor. Internette bir tıkllyorsun önüne geliyor günlük hayatta da aynı şeyi bekliyorsun artık. Olmayınca da daha öfkeli oluyoruz. Hoş görüyü azalttyor. Uğraşmayalım her şey bir düğme olsun.(K3)

Katılımcı11 de bu hayat tarzının insanları aceleci ve fevri yaptığını söylemektedir.

Bu yaşam tarzı bizi çok aceleci ve fevri yaptı. Biraz kişilikle de alakalı sabredip sonucunu bekleyen de var sabretmeyip klavyelere sarılan arkadaşlar bakıyorsun sonra özür dilemeler yanlış anlamalar. (K11)

\section{Kanaat}

Makinelerin çok fazla hayata girmediği dönemlerde yeni ürünün maliyeti ve sahip olunan imkanlar ihtiyaçları sınırlamaktaydı. Katılımcılarımıza göre teknolojinin gelişmesi ile birlikte daha ucuza çok fazla çeşit ürün alabilme imkânı ihtiyaçları, artırmaktadır.

Katılımcı17 de kanaat kavramının kaybolduğunu söylemektedir.

Kanaat etmiyoruz artı daha fazlası olsun diyoruz çünkü imkânlar genişliyor. İnsanın gelir seviyesi arttıkça ihtiyaçları da artiyor. Ama huzur yoksa hiçbir anlamı yok huzuru da manevi şeylerle sağlayabiliriz.(K17)

Katılımc12 elde ettiğimiz bu kadar rahat ve konforun bizi doyumsuz yaptığını, söylemektedir.

Doymuyoruz çünkü doyumsuzluktan çünkü her şey çok güzel ve her şey çok var. (K2)

Katılımcı4 bugünün kullanılan teknolojik imkânların getirdiği konforun sonuçlarına değinmektedir. 
Teknoloji tüketimi daha lüks bir hayat sunuyor. Rahat ve konforlu bir hayat. Şu var işte çamaşır makinesi hayatımıza girmesi ile daha çok tüketmeye başladık. Elle yıkadığımız zamanı hatırladım bir okul klyafetim vardı bir pijama bir de günlük kıyafetim vardı. Bir hafta da kullandığım kıyafet üç tane idi. Şu anda günlük bir tane kullanıyoruz. Şimdi daha fazla kıyafetimiz var daha fazla yıkıyoruz. Daha fazla israf. Kazandı̆̆ımız zamanı geri harcıyoruz. (K4)

Katılımc114 yüksek teknoloji kullanma gerekçesini şu şekilde anlatmaktadır;

Benim param var ben bunun planını yaptım, yardımımı da yapıyorum, görevimi de yapıyorum, helalinden kazantyorum, helaline harcıyorum. Allah verdiği nimeti kulunun üstünde görmek ister. Bu bilinçle allyorsa ameller niyetlere göre ya ben ona hiçbir şey demiyorum yeter ki bu bilinci olsun hani bu kadarının da görüyorum ki bunu diyen var bir de bilinçsizce çarçur edip savuran kesim var. Benim yeteri kadar param olsa en marka araba alabilirim, kendi adıma en güvenlisini, almaya çalışırım çevreye en az zarar vereni almaya çalışırım. En az yakıt kullananı almaya çalışırım. Yine en ekonomik olanı almaya çalışırım yani. İhtiyaç mı lüks mü ihtiyaç araç koltuğuna ne amaçla kullanıyorsun sen. etmektedir.

Katılımc113 kendi yaşantısını ihtiyacın gelire ve bulunduğu statüye göre belirlendiğini ifade

Her şeyi kullanan insanların böyle gerekçeleri var. Adam lüks villa da oturuyor ben çok misafir ă̆ırlıyorum diyor.

Standardım, benim bulunduğum çevreye göre benim yaşantım orta. Bunu nasıl ifade edeceğim. Şu anda ben kendi yaşamı mı irdelediğim zaman israf görüyorum tabi ki. Mesela evime eşya alıyorum bana bunlar çok lüzumlu değil diyor. Ama eşya alıyorum masanın üzerine bir obje alacaksın ihtiyaç mı değil ama orda onu istiyorsun onu. Ísraf gönlüme rahatsızlık veriyor. Ama zevk olarak ta allyorum. Gördüğümüz için olabilir. Görmesen almazsın herhalde. Benim hayatımda gelirime göre değişti. Yani mesela yeni evlendiğimde b u objeleri görmüyor muydum? Görüyordum. Ama keseme uygun değildi. Yani hiç unutmuyorum bir şeyi çok beğenmiştim alacak durumdaki bir arkadaşıma telefon ettim indirime girdiğinde gidip al diye. Ben alamayacak durumda idim. Sonra imkânım oldu ayn objenin belki daha farklısını gittim aldım. Bu gelirime göre değişiyor. Eşya değişince üstündeki, obje de değişiyor. Yani bu bulunduğun çevrenin de bir etkisi var. Ben mesela Ankara siradan bir memur olarak gitseydim herhalde böyle olmazdl. Hem gelirime göre hem statüme göre şekil alacakt.. (K13)

Katılımc12 bulunduğu ortamda kendi statüsünü koruyabilmek için kullanacağı ileri teknoloji araçların ihtiyaç olduğunu ifade etmektedir.

Benim için benim Iphone'numun olması böyle bir çevre de yaşayınca önemli bir şey ama. Onun teknolojisinin gelişmiş olması bana çok çok bir şeyler katmıyor. Bulunduğum çevreye göre. Iphone kullanınca kendimi değerli hissediyorum. Iphone kullanmak kesinlikle statüdür. Kesinlikle araba da telefon gibi sadece 4 tekerleklisi iyi değil. Maddi şartlarla ilgili eşim Range Rover aldi.250 milyar benim ki 25 milyar ben de istiyorum o zaman. B u önemli nasll telefon statü ise araba anahtart da önemli. Araba anahtarın şöyle ortaya koyabilmek. Arabanın olduğunu bilmeleri bile çok önemli oluyor maalesef. (K2)

\section{Tefekkür}

Teknoloji sanal olanla teması artırmıştır. Ekrana odaklı hazır düşünce modellerin sunulduğu yeni teknoloji imkanları, insan derin düşünme ve tefekkürden uzaklaşmaktadır.

Katılımcı 8 de teknoloji yüzünden doğa ile temasın kesildiğini yaratanı tefekkür ortamının yok olduğunu ifade etmektedir.

Allah bize üretme gibi bir kudret vermiş biz onu es geçiyoruz aslında. Birçok şeyi makinelere yaptırlyoruz. Her şeyi hazır alıyoruz Insanlar farklllıklar üretiyorlardl. Çocuklar şimdi sütün süthaneden çıktı̆̆ını zannediyorlar yaratana ve yaratanın bize neler lütfettiğini görme yok o perde kapantyor. Onlar araya giriyor.(K8)

Katılımc19 teknolojinin oyalaması neticesinde insanın hem kendisiyle hem de Allah la beraber olamadığını söylemektedir.

Turkish Studies - Social, 15(3) 
Teknoloji insanın kendiyle ve Allah'la baş başa kalmasını engelliyor. İhtiyaçlı insan Allaha daha çok yalvarlyor. (K9)

Katılımcı5 insanların sosyal medya aracılığı ile paylaştıkları şeyleri beğenisi peşinde olduğunu söylemektedir.

Çok ciddi bir ego kazandırdığını düşünüyorum. Şimdi Facebook'a bir cümle yazıyorum. Burası çok önemli Facebook'ta yazdlğım yazlyı biri beğenmiş mi diye baklyorsam bunun tanımını bulamıyorum. Bunu böyle onaylanmak falan ötesinde başka bir şey bu ama ben bunu daha bulamıyorum. kendime engeller koyuyorum. Çok bilinçli engeller koyuyorum telefonumu uçak moduna altyorum. Niye tekrar açıyorum ben onu. (K5)

\subsubsection{Zaman Farkındalığının Azalması}

Teknoloji ile geçirilen zamanın uzadıkça geçirilen zamanı fark etme durumu azalmaktadır. Dini ritüellerdeki vakitli ibadetler de bu farkındalığın azalmasından dolayı uygulama sıklığı azalmaktadır. Katılımcı10 ve katılımcı9 teknoloji ile geçirilen zamanın ibadeti engellediği üzerinde hem fikirdir.

Ben teknolojiye çok sıcak bakan bir insan değilim açıkçası. Belki çok belki olumlu yönleri de var fakat getiri kadar çok fazla da götürüsü var. Bir Müslüman kadın altyor telefonu saatlerce veya bilgisayarı bir muhabbet sitesinde saatlerini geçirebiliyor. Bize bir hocamız Facebook açtığınız kadar Kur'anı Kerim 'i açıyor musunuz demişti. Facebook' 5 dk baklyorsun ama onun yerine 5 dk Kur'an oku. (K8)

Oyun oynadı̆̆ım kadar Kur'an okusam daha fazla hatim ederdim. (K9)

Katılımcı11 gece geç saatlere kadar internet ve TV başında kalınca sabah namazına kalkmanın sorun olduğunu aktarmaktadır.

Daha çok vaktimi aldı̆̆ını gördüm çünkü internetin başına oturduğum zaman zamanı denetleyemiyorsunuz yarım saat oturuyorsunuz bakiyorsunuz 2 saat olmuş. Uykusuz kalyorum, namaza kalkmak sikintı oluyor.

\subsubsection{Kutlama Geleneği}

Teknolojinin kısa sürede daha fazla insana ulaşma imkânı özel mesajlar yerine tek tip mesajların bir anda çok sayıda insana ulaşmasını sağlamaktadır. Bu durum kutlama geleneğini sanallaştırmış insanın duygusal iletişimini azaltmıştır. Katılımcı15 teknolojinin Dini bayram ve kandil kutlamalarını metalaştırdığını söylemektedir.

Eskiden bir insan bir insanın kandilini kutlamak istediğinde açar kandilin mübarek olsun arkadașım derdi. Hızlı bir değişsimin içindeyiz Babam herkesi arardı. Mesaj atmak ta bir derece de Facebook'ta kandiliniz mübarek olsun deyip çiçek fotosu göndermek hoş değil yani. Göndermek için gönderiliyor. Etkili olduğunu düşünmüyorum. Hem toplumsal gelenekleri yerine getirmek istiyor ama hani teknolojiyi buna alet ediyor.(K15)

\section{Sonuc}

Dindar kadın teknoloji ile arasındaki ilişki yaşam tarzında bir dönüşüm ortaya çıkarmış mıdır? Böyle bir değişiminin mahiyeti nedir? Hangi örnekler üzerinden görünür hale gelmiştir? Bu sorular orijininde gerçekleştirilen bu çalışmada aşağıdaki sonuçlara ulaşılmıştır. Her yeni teknolojinin yeni bir dini yaşam tarzını da beraberinde getirdiği tezi büyük ölçüde geçerliliğini korumaktadir.

Dini yaşama boyutunda teknolojinin getirdiği dini öğrenme kolaylığı katılımcılar tarafindan çok olumlu algılanmaktadır. Kur'an okuma, ezberleme, dinlemede teknolojik aletleri kullanmanın kolaylığı vurgulanmaktadır. Katılımcılar dini bilgiye erişim kolaylığı ve çoğulculuğun, özellikle anne babalarına ait katı geleneksel dini anlayışı yumuşattığ 1 ve dini daha yaşanır kıldığı konusunda hem fikirdirler. Bu durum korkutucu din anlayışının değişimini sağlamaktadır. 
Teknolojinin gelişmesi dinin geleneksel öğrenme, öğretme ve dini yaşama şekillerinde değişme meydana getirmiştir. Eskiden Kur'an-1 Kerim'i öğretme sadece bir hoca nezaretinde öğrenebilirken şimdilerde Kur'an-1 Kerim'i öğretme programları aracılığı ile sanal ortamdan da destekle öğretme yapılabilmektedir. Bu durumun hocanın direkt otoritesinden yoksun olmas1 sebebiyle eskiden mevcut olan öğrenme korkusunun şimdilerde olmadığı vurgusu yapılmaktadır. Bunun yanında önceden mukabele dinlemek yine birebir hocayı dinlemekle gerçekleşirken şimdilerde özel bir ortam ihtiyacı duymadan yine kayıttan dinleyerek mukabele gerçekleştirmek mümkün olmaktadır. Ayrıca hafız olmak için uygulanan hafızlığın geleneksel metoduna alternatif olarak internet üzerinden yapılan hafızlık çalışmaları da görülmektedir. Ayrıca dinin içreğine ait öğrenmeler de ise artık sanal ortamda çok fazla bilgiye ulaşma imkânı tek kaynaklı daha otoriter bilgi ve fetvalar yerine çoğulcu bir anlayış geliştirmiştir. Eskiden dini herhangi bir konu hazırlamak için çok sayıda kitapları taramak ve incelemek gerekirken şimdilerde arama motorları sayesinde aranan bilgi her ne ise herhangi bir kitabın kendisine gerek duymadan tüm ayrıntılarla isteyen kişinin önüne gelmektedir. Bununla birlikte akıllı telefonlarda bulunan namaz vakitleri ve ezan programlar da dindar kadınlar tarafından kullanılmaktadır. Tüm bu durumlar dini bilgilerin ve fetvaların güncellemesini gerektirmektedir. Eskiden Mushaf abdestsiz tutulmazken besmelesiz açılmazken, şimdilerde Kur'an'1 Kerim okuyan kalemler ya da ekranına Kur'an'1 Kerim aktarılan Ipad, laptop ya da akıllı telefonları açarken ya da dokunurken durum ne olacaktır? Ayrıca Kur'an'1 Kerim'i sanal ortamda dinlemekle birebir dinlemek aynı mıdır? Tüm bu verilerin ışığında şu saptama önemlidir; eskiden dini yaşamak için olmazsa olmaz dinin kurumsal (cami, hoca, cemaat, Mushaf) araçlarına şimdilerde çok ihtiyaç duyulmadan dini ritüeller yaşanabilmektedir. Dini yaşama daha öznel bir alana taşınmaktadır.

Dindar kadınların teknoloji ile yoğun uğraşları ile yeni dini yaşam modeli ortaya çıkmıştır. Geleneksel dindar kadınlar için mahremiyet alanı çok keskin iken teknoloji ile kaynaşan dindar kadın için mahremiyet alanı değişmiştir. Kamusal alana çıkarken kendine sınırlar çizen ya da evine gelen yabancılar için belli sınırlar koyan dindar kadın sanal ortamda kendisi evi ile ilgili sınırlar koymamaktadır. Geleneksel dindar kadın fotoğrafla bile arasına mesafe koyarken modern dindar kadın görüntülü aktarım ve paylaşımları sanal kabul etmektedir. Sanal olan da günah kavramı içine girmemektedir. Bununla birlikte dinin günah saydığı bir kişinin aleyhinde konuşmak, sanal ortamda rahatsızlık vermemektedir. Yine başka bir kişiye ait bir şeyi izinsiz almak olan hırsızlık büyük günahken sanal ortamda özellikle kişiye ait bilgilerin vs. alınması yine kişilerde rahatsızlık vermemekte günah hissi uyandırmamaktadır. Bununla birlikte sanal ortamda sahih bilgi araștırması daha az yapılmakta sanal ortam bilgisi sorgulanmadan uygulanmaktadır. Katılımcıların çoğu kişilerin sanal dünya dışında yapılan günah algısının sanal ortamda günah algılanmamasından şikâyetçidir. Müslüman dünyası ekran arkasındaki dünyanın hakikatini kavrayamamakta; bunu sanal kabul etmektedir. Dolayısıyla bu ortamda yapılan birçok şey mubah görülmektedir.

Teknoloji gelişiminin getirdiği üretim hızı tüketimi de beraberinde getirmiştir. Dini yaşam tarzını benimseyen kadınlar sürekli üretilen, daha yeni model ürünleri alma duygusu ve bir dini değer olarak israf etmeme duygusu arasında çelişki yaşamaktadırlar. Dini yaşam tarzını benimseyen kadınlar bu çelişkiyi, modeli daha eski eşyaları vermek şeklinde çözüm üretmiş̧lerdir. Böylelikle hem yeni bir şey alma imkânı hem de daha eski olanı vererek infak etmiş olma duygusu yaşanmaktadırlar. Modern dindar kadın için vermek yeni şeylere yer açmak için eskileri vermek şekline dönüşmüştür.

Teknoloji gelişimi getirdiği gelişimlerden bir tanesi de istenilen şeye hızla ve çok fazla çaba göstermeden ulaşma imkanıdır. Yeni gelişen teknolojinin ulaşma hızı ve konforu bir önceki teknolojinin ulaşma hızı ve konforuna göre daha ileri gitmektedir. Katılımcılarımıza göre bu istenilen şeye hızlı ve kolay ulaşma imkânı insanlardaki gayret ve bekleme duygusunu azaltmaktadır.

Makinelerin çok fazla hayata girmediği dönemlerde yeni ürünün maliyeti ve sahip olunan imkanlar ihtiyaçları sınırlamaktaydı. Katılımcılarımıza göre teknolojinin gelişmesi ile birlikte daha 
ucuza çok fazla çeşit ürün alabilme imkânı ihtiyaçların sınırlarını genişletmiştir. Geleneksel dindar kadının ihtiyaç tanımı ile modern dindar kadını ihtiyaç tanımı değişmiştir. Önceleri zorunlu şeyler ihtiyaçken şimdilerde konfor sağlama da ihtiyaç haline gelmiştir.

Teknoloji sanal olanla teması artırmıştır. Ekrana odaklı hazır düşünce modellerin sunulduğu yeni teknoloji imkanları, insan derin düşünme ve tefekkürden uzaklaştırmaktadır.

Teknoloji ile geçirilen zamanın uzadıkça geçirilen zamanı fark etme durumu azalmaktadır. Dini ritüellerdeki vakitli ibadetler de bu farkındalığın azalmasından dolayı uygulama sıklığı azalmaktadır.

Teknolojinin kısa sürede daha fazla insana ulaşma imkânı özel mesajlar yerine tek tip mesajların bir anda çok sayıda insana ulaşmasını sağlamaktadır. Bu durum kutlama geleneğini sanallaştırmış insanın duygusal iletişimini azaltmıştır.

İnfak, sabır, kanaat, tefekkür gibi dini değerlerin yaşama şekli değişmektedir. Ayrıca teknolojinin geliştirdiği bağımlılık sebebiyle ibadet etme farkındalığının azaldığı, dini geleneksel kutlama biçimlerinin (ziyaret yerine sanal mesajlar) değiştiği ve sanal hurafelerin arttığı sonuçları çıkmaktadır.

Sonuç itibari ile teknoloji kullanımının yaşam tarzını değiştirdiği kanaatine ulaşılmıştır. Bu araştırmanın örneklemi eğitimli ve orta gelir seviyesinde dini eğitim almış, kendini dindar tanımlayan orta yaș kadınlar ile sınırlıdır. Toplumun diğer kesimleri üzerinde benzer çalışmaların yapılması daha bütüncül bir sonuç verebilir. Ayrıca derinlemesine mülakat yönteminde az sayıda katılımcıdan oluşan örneklem ile gerçekleştirildiğinden sınırlı bir perspektif sunmaktadır. Daha çok sayıda katılımcılı örneklemi içeren bir anket çalışması daha geniş bir perspektif sunabilir. $\mathrm{Bu}$ tip çalışmalarla teknolojinin insanların yaşam tarzı üzerindeki etkilerinin farkındalı̆̆ 1 sağlamaya çalışılmaktadır. Bu etkilerin getirdiği olumsuz sonuçları minimize etmek veya yok etmek için nasıl bir çaba gösterilmesi gerektiği de başka bir çalışmanın konusu olabilir.

\section{Kaynakça}

Acar, M. D. Ö. (1997), Sosyal Bilimler Sözlügü, Ankara, Vadi Yayınları.

Aslan, Ö. (2007), Bilgi Toplumunda Teknolojinin ve Teknoloji Politikalarının Yeri, İstanbul Üniversitesi Sosyal Bilimler Enstitüsü İktisat Anabilim Dalı, (Yayımlanmamış Doktora Tezi), İstanbul.

Balkanlığlu, E. (2014), Türkiye'de Muhafazakâr Kadın Modernleşmesi Ve İslami Moda Dergilerindeki Yeni Muhafazakâr Kadın, İstanbul Üniversitesi Sosyal Bilimler Enstitüsü (Yayımlanmamış Yüksek Lisans Tezi), İstanbul.

Barbarosoğlu, F. (2013), Şov ve Mahrem, İstanbul, Profil Yayıncılık.

Basalla, G. (1996), Teknolojinin Evrimi, (çev. Cem Soydemir), Ankara, Tübitak Yayınları.

Beşli, Z. (2005), Teknoloji ve Toplum: Ortaöğretim Öğrencilerinde Teknoloji Kullanımı ve Etkileri,

Coşkun, A. (2007), Din Toplum ve Kültür, İstanbul, İz Yayıncılık.

Çamkara, A. (2007)" Teknoloji Ve Kültürel Endüstri: “Web”ten “Cep’e Alkışların Dönüşümü”, Millî Folklor, 75, 27-29

Demir, A. (1973)," Çağdaș Teknolojik Gelişmeler: Sosyo-ekonomik Etkileri ile Ankara”, Ankara Üniversitesi Siyasal Bilgiler Fakültesi Yayınları No:352. 
Demirci, K. (1995), Teknolojik Değişim Yoğunluğunun Yönetici Tipolojisine Etkisi, Dumlupınar Üniversitesi, Sosyal Bilimler Enstitüsü (Yayımlanmamış Yüksek Lisans Tezi), Kütahya

Göle, N. (2010), Modern Mahrem: Medeniyet ve Örtünme, İstanbul, Metis Yayınları, 10.b, ss.70-77.

Günay, Ü. (2000), Din Sosyolojisi, İstanbul, İnsan Yayınları.

Güven, S. (2003)," Yeni Dünya Düzeni İçinde Enformasyon Teknolojilerinin Vaatleri Ve Tehditleri”, Boğaziçi Üniversitesi, İletişim Fakültesi Dergisi, 0(34): 69-83.

Hökelekli, H. (2010), Din Psikolojisine Giriş, İstanbul, Dem Yayınları

Kline, S. (2003), "What is Technology?" Philosophy of Technology: The Technological Condition. Eds. Robert. C Scharff and Val Dusak. Malden, MA: Blackwell.

Okutan, B. (2012), Türkiye'de Popüler Kültür Din İlişkisi: Kadın Üzerine Bir Araştırma (İstanbul Örneği), Marmara Üniversitesi, İlahiyat Fakültesi (Doktara Tezi), Aralık.

Özaydın, B. (2010)., Teknoloji Kültürü Ve Etik, Süleyman Demirel Üniversitesi Fen Bilimleri Enstitüsü (Yayımlanmamış Yüksek Lisans Tezi), Isparta.

Özdoğan, Ö. (2009), İsimsiz Hayatlar.Ankara, Özdenöze Yayınları.

Özel, İ. (2015), Ü̧̧ Zor Mesele Teknik-Medeniyet-Yabancılaşma, 3.B., İstanbul, Tam İstiklal Yayıncılık Ortaklığı.

Özipek, B. Muhafazakârlık, İstanbul, Timaş Yayınları.

Postman, N. (2009), Teknopoli Yeni Dünya Düzeni, Paradigma Yayıncılık, İstanbul.

Savc1, İ.” Toplumsal Cinsiyet Ve Teknoloji”, A.Ü. Siyasal Bilgiler Fakültesi Dergisi, 54(01):1-56.

Slattery, M. (2008), Sosyolojide Temel Fikirler, (çev. Ümit Tatlıcan-Gülhan Demiriz), İstanbul, Sentez Yayınları.

Subaşı, N. (2014), Din Sosyolojisi, İstanbul, dem Yayınları.

Şentürk, E. Ayten, G. İlknur, M., Köksal, F. Ünal, G. (2011), Teknoloji ve Kadın Sağlığı, Acıbadem Üniversitesi Sağlık Bilimleri Dergisi, 2(2), 5-37.

Şişman, N. (2003), Emanetten Mülke: Kadın Bedeninin Yeniden İnşası, İstanbul, İz Yayıncılık.

Şişman, N. (2015), Küreselleşmenin Pençesi İslam'ın Peçesi, İstanbul, İnsan Yayınları.

Tekin, M. (2004), Kutsal, Kadın ve Kamu: Türkiye'de Aydın Kadınlara Göre Din ve Kadın, İstanbul, Açılım Kitap Yayınları.

Thomas S.K. (2008), Bilimsel Devrimin Yapısı, çev. Nilüfer Kuyaş, İstanbul, Kırmızı Yayınları.

Turan, S. (2006)," Bir Meşrulaştırma Aracı Olarak Bilişim Ve Kitle İletişim Teknolojileri: Eleştirel Bir Bakış", Eskişehir Osmangazi Üniversitesi İBF Dergisi, Ekim, 1(2), 71-86.

Ural, Ş. (2002).,"Felsefe ve Teknoloji”, Kutadgubilig, Felsefe-Bilim Araştırmaları, 2, 237-247.

Uygur, N. (1989), Çă̆daş Ortamda Teknik, İstanbul, Yapı Kredi Yayınları.

Ünalan, S. (2013), Çalışma Hayatının Dindar Kadının Dini Anlayış Ve Uygulamalarına Etkisi Üzerine Sosyolojik Bir Araştırma, Uludağ Üniversitesi, Sosyal Bilimler Enstitüsü (Yayımlanmamış Yüksek Lisans Tezi), Bursa

Üşür, İ. (2009),"Teknoloji Felsefesi Üzerine ya da Tarihin Tanrısı Teknoloji midir?", Mülkiye Dergisi, XXV, 230, 7-26. 
Yiğit, E. Çengelci, T. Karaduman, H. (2013)," Teknolojinin Değerlere Yansıması Konusunda Sosyal Bilgiler Ögretmen Adaylarının Görüşleri” Sosyal Bilgiler Eğitimi Araştırmaları Dergisi, 4(1), 73-96

Yörükoğulları, E. (2013), Bilim ve Teknoloji Tarihi, Anadolu Üniversitesi Yayınları.

Yücebaş, S. (2012),'’Türkiye'de Muhafazakârlığın Gündelik Yaşam Estetiği' 'İnsanbilim Dergisi, $1,62-80$.

\section{EK 2: Katılımcilar}

\begin{tabular}{|c|c|c|c|c|c|c|}
\hline Sira No & $\begin{array}{l}\text { Doğum } \\
\text { Tarihi }\end{array}$ & $\begin{array}{l}\text { Lise } \\
\text { Eğitimi }\end{array}$ & Eğitim Durumu & Meslek & Eş Mesleği & $\begin{array}{l}\text { Çocuk } \\
\text { sayıs1 }\end{array}$ \\
\hline Katılımeı 1 & 1969 & İHL & Tıp Fakültesi & Doktor & Doktor & 4 \\
\hline Katılımcı 2 & 1979 & İHL & Hukuk Fakültesi & Avukat & Avukat & 2 \\
\hline Katılımcı 3 & 1980 & İHL & $\begin{array}{l}\text { İlahiyat } \\
\text { Fakültesi } \\
\end{array}$ & $\begin{array}{l}\text { Araştırma } \\
\text { Görevlisi }\end{array}$ & Mühendis & 1 \\
\hline Kat1lıme1 4 & 1972 & İHL & Biyoloji Bölümü & Öğretmen & Genel Müdür & 3 \\
\hline Kat1lımc1 5 & 1960 & KOLEJ & $\begin{array}{l}\text { İlahiyat } \\
\text { Fakültesi }\end{array}$ & Okul Yöneticisi & Okul Yöneticisi & 5 \\
\hline Kat1lımc1 6 & 1982 & İHL & $\begin{array}{l}\text { İlahiyat } \\
\text { Fakültesi }\end{array}$ & $\begin{array}{l}\text { Kur'an Kursu } \\
\text { Ögrretmeni }\end{array}$ & Mühendis & 2 \\
\hline Katılımc1 7 & 1973 & Medrese & & & Doktor & 3 \\
\hline Kat1lımc1 8 & 1981 & Düz Lise & $\begin{array}{l}\text { İngilizce } \\
\text { Öğretmenliği }\end{array}$ & Ev Hanımı & $\begin{array}{l}\text { Mühendis } \\
\text { Müteahhit }\end{array}$ & 2 \\
\hline Kat1lıme1 9 & 1982 & Düz Lise & Sosyoloji & Memur & Pazarlamac1 & 1 \\
\hline Katılımc1 10 & 1976 & İHL & $\begin{array}{l}\text { İlahiyat } \\
\text { Fakültesi }\end{array}$ & $\begin{array}{l}\text { Kur'an Kursu } \\
\text { Öğretmeni }\end{array}$ & $\begin{array}{l}\text { Mühendis } \\
\text { Müteahhit }\end{array}$ & 2 \\
\hline Katılıme1 11 & 1973 & KOLEJ & Biyoloji Bölümü & Ev Hanımı & Tekstilci & 3 \\
\hline Katılımc1 12 & 1978 & İHL & $\begin{array}{l}\text { İlahiyat } \\
\text { Fakültesi }\end{array}$ & $\begin{array}{l}\text { Anaokulu } \\
\text { Öğretmeni }\end{array}$ & $\begin{array}{l}\text { Yönetici } \\
\text { Mühendis }\end{array}$ & 2 \\
\hline Katılımc1 13 & 1969 & Medrese & & Ev Hanımı & Milletvekili & 2 \\
\hline Katılımc1 14 & 1979 & Düz Lise & $\begin{array}{l}\text { Uluslararsı } \\
\text { İlişkiler }\end{array}$ & $\begin{array}{l}\text { Araştırma } \\
\text { Görevlisi }\end{array}$ & Mühendis & 2 \\
\hline Katılımc1 15 & 1980 & Düz Lise & $\begin{array}{l}\text { Edebiyat } \\
\text { Fakültesi }\end{array}$ & $\begin{array}{l}\text { Araştırma } \\
\text { Görevlisi }\end{array}$ & $\begin{array}{l}\text { Araştırma } \\
\text { Görevlisi }\end{array}$ & - \\
\hline Katılımc1 16 & 1972 & Medrese & $\begin{array}{l}\text { Arap Dili } \\
\text { Edebiyat1 }\end{array}$ & Medrese Hocas 1 & Bekar & - \\
\hline Katılımc1 17 & 1980 & $\overline{\mathrm{İHL}}$ & $\begin{array}{l}\text { İlahiyat } \\
\text { Fakültesi }\end{array}$ & $\begin{array}{l}\text { Kur'an Kursu } \\
\text { Ögrretmeni }\end{array}$ & $\begin{array}{l}\text { Öğretim } \\
\text { Görevlisi }\end{array}$ & \\
\hline Katılımc1 18 & 1973 & Düz Lise & $\begin{array}{l}\text { Endüstri } \\
\text { Mühendisliği }\end{array}$ & Ev Hanımı & $\begin{array}{l}\text { Yönetici } \\
\text { Mühendis }\end{array}$ & \\
\hline
\end{tabular}

